be much more intense and brilliant in places where the fresh water dripped or trickled over the rocks than where they were comparatively dry. In the first of these the crust was of "a dark blood-colour," in the last "a brick-red." But among the former he observed some patches which were "a bright orange." This he attributed to a fuller state of fructification, but neglected to put up specimens. It may, however, be doubted whether this last colour did not originate in an excess of fresh water, which we know changes to orange the red of many Floridea, as particularly observed in Nitophyllum versicolor.

Probably this production is common in similar situations on other of the British coasts, but, with numerous others of the crustaceous class of Algæ (a neglected group, which will repay in novelty an observer who has patience to look for them), has been hitherto unnoticed or passed by. Though our information respecting it is still imperfect, its characters are such as to exclude it from any established genus with which I am acquainted. The brilliant red colour and substance sever it from Ralfsia, Berk. (Padina? deusta, Hook.), which in habit it more nearly resembles than any other British plant; but this is a resemblance of habit alone, and therefore more one of analogy than affinity. With the Mediterranean Peysonellia it has, seemingly, more affinity, and it is in the neighbourhood of that genus that I propose, for the present at least, to place it.

W. H. H.

\title{
EXPLANATION OF PLATE II.
}

Fig. 1. Rhododermis Drummondii, natural size.

Fig. 2. Portion near the margin, magnified.

Figs. 3 and 4. Different views of tubercles.

Fig. 5. Portion of the surface highly magnified.

X.-Researches on the Organization of the Invertebrate Animals of the Western Coast of France. By M. De Quatrefages. Communicated by Alfred Tulk, M.R.C.S.

The admirable report of M. Milne Edwards upon this subject, to which want of space in a recent number of this Journal admitted only of briefly directing the attention of the reader, contains amongst others a most valuable series of observations by M. Quatrefages relative to the organization of certain Gasteropoda, which have hitherto been incorrectly associated with the genus Doris under the general title of Nudibranchiata, but which differ much, through the degradation of their internal structure, from all the ordinary Mollusca. As regards the general form of their body, the generative organs and the position of the central nervous ganglia, these animals resemble the other Gasteropoda, 
but are widely separated from the normal type of that group by the structural conditions under which the functions of circulation, respiration and digestion are performed. The great physiological distinction in the nature of the circulatory apparatus of the class Mollusca and Articulata consists in its being provided in the former with two systems of membranous vessels united at one end by the intervention of a heart, and communicating at the other by a network of capillaries, while in the latter one of these systems (the afferent or venous) is always wanting, and is supplied by lacunæ or intervals between the different organs, within which the blood flows. Some years ago M. Quatrefages had determined the fact, that in the compound Ascidia and several other molluscoid animals, the vascular system only existed in the thoracic region of the body, and was replaced throughout the abdomen by interstitial meatuses resembling those in the Articulata; and that in the Bryozoa the inferior representatives of the same zoological type, there existed no blood-vessels whatever, and the nutrient fluid was distributed through large cavities of the body. Hitherto however no true mollusk was known in which the circulation was not completely vascular, nor could it have been well anticipated that one of the highest groups of the class should present the contrary character; still the Eolidians and other analogous Gasteropoda have furnished such a structural degradation in different degrees. In the first a well-developed heart and arteries exist, but no proper veins, the blood being returned by means of a system of irregular lacunæ similar to those met with in the Crustacea; while in other species both the heart and arteries have disappeared, and the circulation becomes as incomplete as in the Bryozoa.

Corresponding modifications are entailed by the above in the structure of the respiratory organs. There are no branchiæ or pulmonary sacs in the present Gasteropoda, as in the ordinary Mollusca : respiration is either simply exercised by the general surface of the integument, or limited to particular appendages upon the back of the animal ; but even in the latter ease no vascular network enters into their composition, and to supply this deficiency, nature has introduced a combination of the digestive with the respiratory system, that was hitherto believed to occur only in the Medusæ and different Entozoa. The digestive cavity gives off a system of canals, the ramifications of which penetrate the branchiform dorsal appendages, and within these the nutritive matters, being directly conveyed, are submitted to the influence of the air before being sent to the various parts of the body. This complex vasculo-gastric system has been elaborately studied by M. Quatrefages in the genus Eolidina ; in others it is constructed upon a more simple plan, reminding us of that of the 
digestive cavity in some Hirudines and Planaric. In the genera Pelta and Chalidis no ramified appendages are found, but only two large sacs, into which the alimentary substances enter and remain for some time.

The nervous system is also less perfect than in the ordinary Gasteropoda, and approximates the Tunicata; the postœesophageal or ventral ganglia, and the transverse commissure uniting them and completing the œsophageal ring posteriorly, being frequently wanting, as are likewise the labial ganglia.

For the reception of these peculiarly-organized Gasteropoda, M. Quatrefages proposes the establishment of a new order in that class, to be called Phrebentera, and which, with the genera already mentioned, must include the genus Actcon, confounded hitherto with the Aphysians, and, in all probability, Glaucus, the Placobranchiata, and all other Gasteropods deprived of lungs and vascular branchiæ. Lastly, certain Planaria may perhaps be inserted under the same group.

M. Quatrefages has also given to science a most instructive memoir upon those polyps which, under the form apparently of rugose amorphous crusts, are frequently found upon the whelkshells inhabited by the Paguri or hermit-crabs; the species had however always been confounded with the Hydra squamata of Müller, and neither its structure or mode of reproduction had been studied. These polyps, designated by our author under the name of Synhydra parasita, live attached by their base to a common laminiform floor supported internally by a corneous network and analogous to the polypary of the Gorgonia, but of a more simple structure, resembling that of the skeleton of the sponge. Thus associated simply in colonies by their bases, we might suppose that each individual polyp exercised its functions independently of another; but they are in fact all united by a system of capillary canals lodged deeply within the common basilar tissue, and which establish ready communications between their respective stomachs.

The same arrangement for rendering the alimentary matters digested by a single polyp available to the nutrition of the entire colony may be observed also in the Alcyonia, the Corallinea, the Gorgonia, Cornularia, \&c., but previous to the discovery of M. Quatrefages was unknown to occur in the Hydras. Another particularly interesting fact is the singular structure of a certain number of these polyps thus united in a kind of tuft. The one kind present the usual form of Hydras, having a mouth surrounded by filiform tentacles, so that they can directly obtain food; while the others are destitute both of oral orifice or appendages, and depend solely for nutrition upon the products of digestion in the former being conveyed to them by the system of 
canals already mentioned. Living thus as parasites, they yet perform important uses in the œconomy of the polypary, since, charged with the process of reproduction, they appear specially destined to ensure the establishment of new colonies.

M. Quatrefages has seen the Synhydre propagate by three very distinct methods. In the one case the young individual proceeds from a bud formed upon the surface of the common basilar tissue, and which is developed nearly in the same manner as the reproductive gemmules of the Hydras and Sertularias; in another, ovules like those of the sponge arise in this common tissue; and lastly, reproductive bodies (bulbilli) are met with upon the free portion of the polyps, which cannot be likened either to gemmæ or ovules, for they grow by an extension of their tissue like the first, and, like the second, separate completely from the parent stem before becoming developed into new individuals. The reproductive gemmules serve to increase the population of the colony in the midst of which they are formed; the ovules remain probably buried in the basilar tissue after the winter has destroyed the polyps covering it, and produce other Hydras on the following spring; while lastly the bulbilli, becoming detached and borne afar by the currents, fix themselves at length in some appropriate spot, develope, and multiplying again by gemmæ, found a new colony, in a manner similar to that by which the compound Ascidia disperse to a distance their sessile societies by means of locomotive larvæ. These bulbilli are exclusively produced by the astomatous polyps, around the summit of which they are grouped, the polyps provided with a mouth appearing not to participate in any degree in the work of generation. The first then are the reproductive, the second the nutrition-serving individuals, and both exhibit corresponding differences of structure. The tentacles of the reproductive polyps are represented only by tubercles, and their digestive cavity resembles that of a polyp whose development is not completed and the stomachic cavity not yet open externally. Arrested as regards the functions of nutrition and of animal life, all the energies of their organism seem concentrated upon the exercise of the generative power; for there is nothing that could lead us to suppose that the nutritory individuals are males, and the astomatous females; but rather that the two great physiological acts, the one necessary to the preservation of individual life, and the other destined to perpetuate the existence of the species, are here exhibited under a separate and independent form in the same community. This mode of propagation by bulbilli in the Synhydra constitutes a form of reproduction not hitherto well determined to occur in the animal kingdom, and we cannot therefore peruse the beautiful researches of M. Quatrefages without feeling their interest no less as bear- 
ing upon general physiology than upon the special history of the polyps.

A third series of researches by the same author has been devoted to the study of the organization of the Annelida, with a view of determining how the dominant type of that natural group is modified or lowered either in the inferior species, or in those worms which have been ranked by many zoologists among the Entozoa. $\mathrm{He}$ has ascertained, in examining the comparative anatomy of the nervous system in Eunice, Nereis, Phyllodoce, Glycera, and some other newly discovered genera, that the ganglionic system is far more complex than has been supposed, and exhibits specific modifications analogous to those which have been observed in Insects and Crustacea.

The vascular system in all the Annelida studied up to the present time by anatomists has been found to present a very considerable amount of development. In some however, as in certain Tubicola, M. Quatrefages has proved that the circulation is not performed by vessels, but through lacunæ situated between the different organs : thus, in a species of Amphicora, very nearly allied to that discovered by M. Ehrenberg, the blood, easily recognisable from its green colour, is not inclosed in vessels, but between the subcutaneous muscular layer and the kind of mesentery that envelopes the alimentary canal ; and lastly, in a new genus of Annelida Errantia allied to Syllis, and called by our author Doyeria, there exist only imperfect rudiments of a vascular apparatus, which is reduced to a simple dorsal vessel.

The genus Aphlebine of M. Quatrefages furnishes another striking example of such organic degradation. In the ordinary Annelida the circulation is performed as in the higher animals, by the alternate contraction and dilatation of a part of the vascular system ; but in the present genus, the blood, instead of being propelled by any organ analogous to a heart, is set in motion by the repeated strokes of a series of microscopically minute palettes, which are composed of vibratile cilia united in that form, and placed upon the walls of the visceral cavity behind the base of each foot. An analogous mechanism has been observed by Milne Edwards in the Beroes.

The affinity of internal structure which previous observers had perceived to exist between the Annelida and Rotatoria has been rendered still more intimate by another discovery of M. Quatrefages, who found upon the coasts of Brittany an Annelide much resembling in general conformation a young Syllis, but which supported upon either side of its body a series of locomotive organs analogous to the vibratile discs of the Rotifers, and so disposed as to simulate when in motion the revolutions of a paddle-wheel. The feet in this singular Annelide, designated by the name of 
Dujardinia, are furnished with bristles as in the other Annelida Errantia; but these are merely passive weapons of defence, since they remain perfectly immoveable. Sometimes the animal changes its position in the water by agitating its tail briskly like a long oar, but in general it swims slowly by means of the above-mentioned lateral palettes, which consist of cilia circularly arranged upon the edges of cup-shaped cavities, supported by papillæ placed upon the sides of the body and between the feet. In the form of its digestive tube and the large size of its ova, Dujardinia also approximates the Rotifera.

Some further details are of interest from tending to indicate the links whereby the Annelida are connected to the Planariae and Entozoa. Thus the Nemerte agree with the Annelida in the general arrangement of their vascular system, but resemble much the Hirudines in the structure of their buccal apparatus and many other points of internal organization, while their reproductive organs are analogous to those of many Entozoa; their nervous system may be compared to that of the Lingula, and their digestive tube, in place of extending the whole length of the body and opening posteriorly by an anal orifice, as in all the typical Annelida, terminates towards the anterior third of the body in a cul-de-sac which communicates externally by the mouth alone, as in some of the lower organized Entozoa and most Zoophyta.

The very singular observations made by M. Quatrefages upon the propagation of the genus Syllis have already been given in a previous number of this Journal. It remains only for us to add, in respect to the Annelida, that in a large number of the Annelida Errantia , and Tubicola, and also in the Thalassema and Nemerta, which establish the passage between the ordinary Annelida and Entozoa, he has recognised the existence of distinct male and female individuals, has observed the formation of the spermatozoa in the Nemerta, and by his remarks upon the development of the ova in the Terebella, has extended to the class Annelida the important fact determined by Herold, Rathke, and other embryologists, respecting the relation of the vitellus to the dorsal surface of the embryo in Insects, Arachnida and Crustacea.

Lastly, M. Quatrefages, in examining the mechanism of motion in the polyps of the genus Edwardsia, has arrived at the same conclusions with $\mathrm{Mr}$. Bowman relative to the theory of muscular contraction; for he has observed that the fibres of one and the same muscle do not all act simultaneously, but that those which contract, drawing along with them the adjacent fibres in a state of repose, give rise to the zigzag folds which have been considered as the efficient cause of the shortening of the muscle.

Touching the subject of animal phosphorescence, our author has been led, from the microscopic study of the small transparent Ann. \& Mag. N. Hist. Vol. xiv. 
Annelida, to infer that its production depends very intimately upon the influence exerted by the nervous system in giving rise to muscular contraction. This, observes Milne Edwards, becomes highly probable from the fact, that in the Beroes of the Mediterranean Sea I have constantly remarked that their very brilliant light emanated from the ciliated sides of the body, the principal seat of the locomotive function.

XI.-Further Observations on the Ornithology of the neighbourhood of Calcutta. By Edward Blyth, Curator to the Museum of the Asiatic Society of Bengal. With Notes by H. E. StrickLAND, M.A.

Calcutta, March 18, 1844.

THe cold season of 1843-44 having now terminated, and the time for collecting specimens of the feathered class fast drawing to its close, I shall again pass under review the various species of birds which I have hitherto succeeded in procuring in this immediate neighbourhood, a task to which I am partly impelled by perusal of Mr. Strickland's interesting 'Notes' (vol. xiii. pp. 32 et seq., ante), which have just reached me.

Nos. 1 and $4 *$. Palcoornis Alexandri and P.pondicerianus. Both of these are strictly hill species, and I doubt if either of them is ever met with in the vicinity of Calcutta. With reference to the enumeration of the species of this genus which I appended in a note, I may remark that there is a "Psittacus (Conurus) himalayanus" of Lesson described in the 'Zoologie du Voyage de M. Bélanger,' p. 239, which is doubtless a Palcornis, and would seem to resemble $P$. schisticeps, except in having the under parts to the belly uniform ash-gray. "Inhabits the valleys of the Himalaya." I have never seen it.

The Psittaculus vernalis appears also to be exclusively a hill species.

Of the Raptores, I have prepared an elaborate monograph of the Indian species, wherein a very considerable number of synonyms have been reduced, and which is at prêsent awaiting publication.

The whole of the true Falcons of India appear to visit this neighbourhood during the cool season, with the exceptions of $F$. Aldrovandi, which I have only seen from the Himalaya, and the $\boldsymbol{F}$. cherrug of Hardwicke and Gray, which is evidently the lanner, $\boldsymbol{F}$. lanarius, and which is not yet well established as Indian, though the name $\boldsymbol{F}$. cherrug occurs in a MS. catalogue of the birds of Nepal prepared by Mr. Hodgson. I have somewhere read that a large falcon called Cherg or Cherrug is highly esteemed in Persia for flying at bustards and other large game: and there can be little doubt that the lanner

* These numbers refer to Mr. Blyth's paper, Annals, vol, xii. p.90, and vol. xiii. pp. 113, 175. 


\section{$2 \mathrm{BHL}$ Biodiversity Heritage Library}

Quatrefages, A. de. 1844. "X.-Researches on the organization of the invertebrate animals of the Western Coast of France. Communicated by Alfred Tulk, M.R.C.S." The Annals and magazine of natural history; zoology, botany, and geology 14, 28-34. https://doi.org/10.1080/037454809495131.

View This Item Online: https://www.biodiversitylibrary.org/item/19582

DOI: https://doi.org/10.1080/037454809495131

Permalink: https://www.biodiversitylibrary.org/partpdf/38111

\section{Holding Institution}

Natural History Museum Library, London

\section{Sponsored by}

Natural History Museum Library, London

\section{Copyright \& Reuse}

Copyright Status: Public domain. The BHL considers that this work is no longer under copyright protection.

This document was created from content at the Biodiversity Heritage Library, the world's largest open access digital library for biodiversity literature and archives. Visit BHL at https://www.biodiversitylibrary.org. 